\title{
EMERGENCY REPAIRS TO THE MAIN BREAKWATER OF CALSHOT HARBOUR ON TRISTAN DA CUNHA ISLAND
}

\author{
Paul Bouton ${ }^{1}$, Frans van Eeden ${ }^{1}$, Marthinus Retief ${ }^{1}$, Francois De Roubaix ${ }^{1}$ and Johan Kieviet ${ }^{2}$
}

\begin{abstract}
The breakwater at Tristan da Cunha suffered structural damage during heavy seas that battered the island during winter 2010 (June and August). The damage was of such a nature that emergency repairs had to be designed and constructed before the onset of the next winter season. The damage entailed the loss of primary armour units (3.5t dolosse) at the head of the western breakwater exposing the under-layer rock as well as some slight movement of the end section of the crest slab (cap). Further damage to the breakwater head (130m offshore in $6 \mathrm{~m}$ water depth) was reported one month later; with the crest slab being lifted further by approximately $500 \mathrm{~mm}$. The construction methodology during the emergency repair design process, laboratory validation and onsite construction is covered in this manuscript.
\end{abstract}

Keywords: Tristan da Cunha; Calshot Harbour; emergency breakwater repair; physical modelling

\section{INTRODUCTION}

Tristan da Cunha is an Overseas Territory of the United Kingdom. It is of volcanic origin and consists of four islands - Tristan (the main island), Nightingale and Inaccessible, (which together form a group) and Gough Island which lies 320 kilometres to the south-east. The total land area is about 310 square kilometres and there is only one settlement, "Edinburgh of the Seven Seas", known almost universally as "the Settlement", inhabited by a population of 271 people. It is situated roughly 2800 kilometres southwest of Cape Town and can be reached only by sea. Access to land is through Calshot Harbour which is the only harbour to serve vessels landing at Tristan da Cunha, see Figure 1.

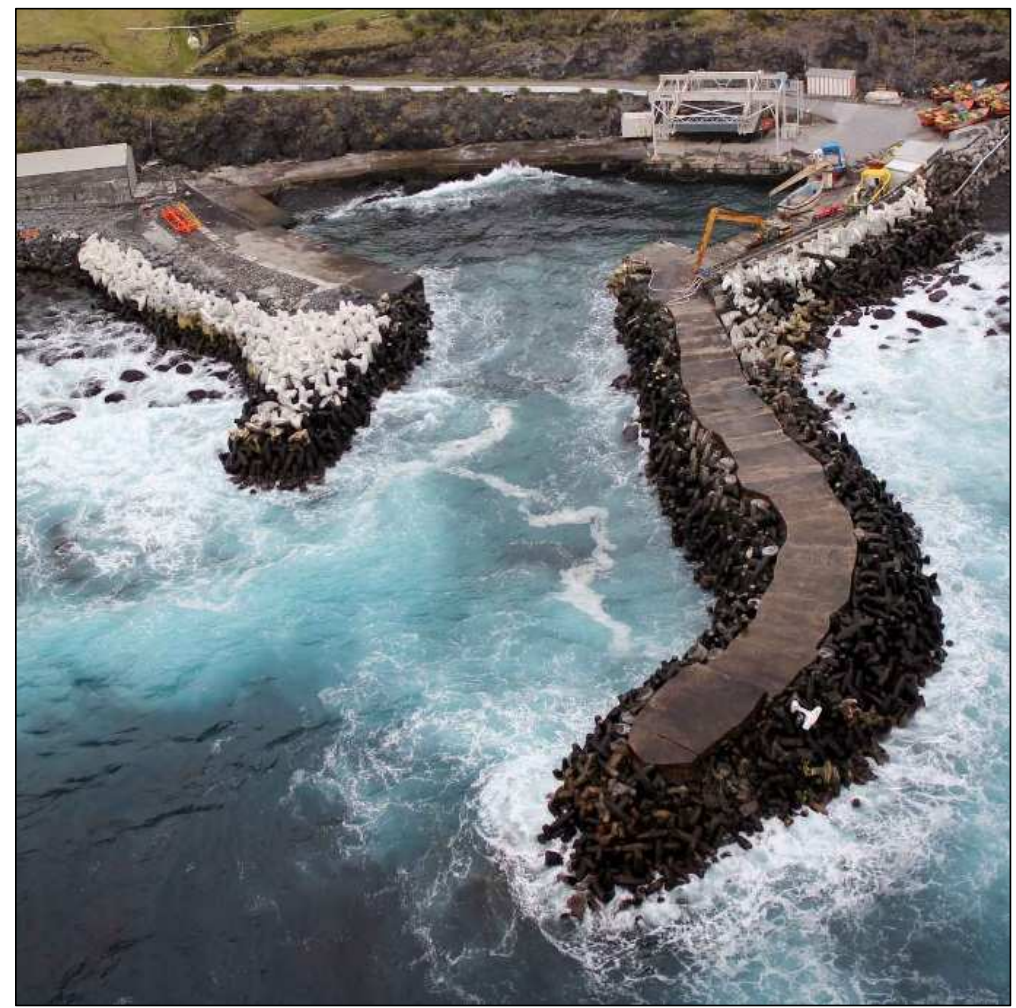

Figure 1. Aerial view of Calshot Harbour taken towards the South from helicopter during transfer of the survey team to land from SA Agulhas on arrival at Tristan da Cunha, 9 September 2010 (WSP, 2011).

\footnotetext{
${ }^{1}$ WSP | Parsons Brinckerhoff, Coastal and Port Engineering, Stein House, Brandwacht Office Park, Trumali Street, Stellenbosch, Western Cape, 7600, South Africa

${ }^{2}$ Council for Scientific and Industrial Research, Hydraulic Laboratory, 11 Jan Cilliers Street, Stellenbosch, Western Cape, 7600, South Africa
} 
The following aspects makes this island unique:

- From the waterline the coastline almost immediately rises at a steepness of approximately $1: 1$. There is thus no suitable area of coastline to construct a harbour.

- The water depth falls to -50 m MSL, roughly100 m from the waterline.

- Tristan da Cunha is extremely far from any mainland and the harbour infrastructure and hinterland facilities are so limited that the maximum weight of freight transported to the island per barge or landing craft is approximately $10 \mathrm{t}$.

\section{HISTORY AND CONSTRUCTION OF CALSHOT HARBOUR}

The western and eastern dolos breakwaters are the main protective elements of Calshot Harbour as it is today but, since they were designed and built in the mid 1990's, very little information is available on their design philosophy or even on their design profiles or as-built profiles. However, this much is known:

\section{History of Construction, Damage and Repairs}

Construction of Calshot harbour was originally started in the middle 1960's. Between 1963 and 1965 two breakwater arms manufactured from gabions and small rock was constructed. By 1990, dolos layers were added to both breakwater arms.

Significant extensions to the breakwater arms were added with dolosse between 1992 and 1994 along with deepening of the basin. Dolos sizes ranged from $1.8 \mathrm{t}$ to $3.5 \mathrm{t}$ and the design slope of the dolos armouring is referred to as a 1:1 slope in the documents of Allan Lloyd Partnership. The precise work conducted, design cross sections and as-built drawings were not available. Although it is believed that the core is made up of rock material obtained from the adjacent beaches, important information on the nature of the core of the existing western breakwater and its foundation at the seabed is lacking. It is apparent from some documents that the core has rocks (up to $3 \mathrm{t}$ ) in places but in other places it has remnants of old dolos roundheads formed as the extensions progressed meaning that there may well be dolosse in the core itself in places.

The western breakwater was reported by Webb (1999) during an inspection as being damaged and appearing steeper in places than the constructed 1 in 1 profile. It is also reported that the dolos slope rested on a bed of large rocks and did not extend all the way to the seabed.

It was reported in January 2004 that the "steep profile of the dolos armouring" was a "most serious shortcoming" and that "failure is likely within a very short period of time" (Halcrow 2005). The findings of Halcrow (2005), based on initial studies, were that the entire outer half of the western breakwater should be replaced by heavier units at a flatter slope. $5 \mathrm{t}$ and $12 \mathrm{t}$ Core-Loc units were proposed.

Between 2006 and 2007 photographic and physical surveys of the breakwaters were conducted by Halcrow and addressed the repair works necessary based on the Halcrow (2005) report. The armouring repairs focused more on the east than the west breakwater. The strategy at the most vulnerable section on the western breakwater was to provide replacement dolos units of the same small size ( $3.5 \mathrm{t})$ to fill the eroded slope area above water over about a $15 \mathrm{~m}$ section "to replicate the as built condition" of 1994.

Emergency repairs in early 2008 to quay and deck slab were carried out by the Military Construction Force (MCF) of the Ministry of Defence of the UK.

The first quarter of 2009 saw repairs to the dolos slope (by external contractor) on both breakwaters but no extension of breakwaters or layout changes. All new dolosse placed were $3.5 \mathrm{t}$ mainly on the eastern breakwater and in the most vulnerable section of the western breakwater (white dolosse seen in Figure 1). However, damage to the breakwaters was once again reported by the local Public Works Department in their ongoing maintenance survey between April 2009 and January 2010. This already showed six new dolosse missing from the western breakwater and reported severe vulnerability of the western breakwater in that "any future storm may lead to failure of the breakwater". It is clear that damage at the vulnerable section on the seaward side of the outer western breakwater was progressing rapidly despite the repairs done less than 9 months previously.

Damage sustained to the root of the Western Breakwater of Calshot Harbour in Tristan da Cunha was reported on 9 July 2010. This entailed loss of primary armour units ( $3.5 \mathrm{t}$ dolosse) at the head of the western breakwater exposing the under-layer (rock), as well as some slight movement of the end section of the crest slab (cap). Further damage to the Western Breakwater head was reported on 10 August 2010, lifting the crest slab by approximately $500 \mathrm{~mm}$ of its $800 \mathrm{~mm}$ height. Total length of the breakwater crest is approximately $130 \mathrm{~m}$.

A WSP survey team was dispatched in September 2010 to assess the damage sustained to the breakwater, design short term repair options and design long term rehabilitation measures. It was found 
by WSP (2010) that a large scour hole had formed on the seaward side of the western breakwater head which resulted in the dislodgement and breaking of the dolos armour layer and the displacement of the breakwater capping slab, see Figure 2.



Figure 2. Photo taken 12 Sept. 2010 towards the south south-east showing the undermined deck slab and exposed core rocks near the head of the western breakwater (WSP, 2011).

In summary, it appears that the layout which was provided by the construction efforts in 1992-1994 has not been extended further or modified since that date apart from the limited repairs conducted in 2008-2009. These limited repairs comprised thickening of the deck, some quay wall repairs and the placement of dolosse above the waterline at some vulnerable locations on the east and west breakwaters. On the western breakwater almost all of 2009's newly placed dolosse have suffered storm damage and been lost or broken as part of a further progression of the damage to the breakwater as a whole which has proceeded almost unabatedly in recent storms. Subsequently, the head of the Western breakwater was severely damaged in July 2010 where dolos armour units were lost and the capping slab lifted.

\section{Breakwater construction methodology and philosophy}

Vonk (2006) reports that it was anecdotally communicated to them that, during construction, the dolosse were placed on the rocky reef and built up in a strong interlocking stack from either side before the rock core was placed in the middle. They reported that this had the effect of locking the dolosse into the core of the breakwater, but also resulted in the outer flukes of the dolosse being upright in a steep "fence pole" pattern. This method of fixing the dolosse into a rock core could not be substantiated either on site (in discussion with villagers) or in any of the reports at WSP's disposal.

A review of the breakwaters a few years after construction is reported in Webb (1999) which states that the armour slope appeared "much steeper than the intended 1:1 profile" and that this appeared to have been achieved by wedging dolos units together in a close knit pattern.

In terms of design philosophy it appears that a steep 1:1 slope was aimed at in the original design of the dolos slopes in the early 1990's. This is briefly discussed in Halcrow (2005) where it is mentioned that the design philosophy seems to have been to rely on very strong interlocking at steep slopes which is a high risk strategy in the case where the units begin to break or shift and the integrity of the slope can be rapidly lost leading to a more catastrophic collapse than would have been the case with a more traditional design of flatter slopes and heavier units.

Halcrow (2005) conclude that the breakwater design philosophy adopted in the 1990's for Tristan da Cunha was to accept steep slopes with a strongly patterned placement of units, with high interlocking and low porosity. Halcrow (2005) also concludes that this has created a breakwater which is either "robust" or "catastrophic".

\section{Emergency repair}

Following the damage to the breakwater in July 2010, the immediate course of action was to stabilise the systematic collapse of the breakwater at the vulnerable section of the western breakwater head. The 
most critical area that required immediate attention was the area where the dolos armour and core material was displaced and the concrete capping was undermined.

It was decided to stabilise the scour hole with $10 \mathrm{t}$ dolos armour units as a temporary emergency repair. In order to achieve this, it was necessary to procure a large heavy lift crane for placing concrete units up to $10 \mathrm{t}$ in weight at 20-30 $\mathrm{m}$ off the breakwater.

It was established from calculations that roughly 75 pairs of $10 \mathrm{t}$ dolos units were needed for the repair. The planned vessel to leave for Tristan da Cunha however had size constraints in its cargo area. To overcome this 75 pairs of $10 \mathrm{t}$ dolos units were precast in halves in Cape Town. These 75 pairs of half cast units along with the heave lift crane in disassembled form and other required construction material were eventually shipped to Tristan da Cunha. The half cast units were joined together via in-situ stitch casting on the island and the heave lift crane assembled.

\section{EMERGENCY REPAIR DESIGN PARAMETERS}

A 1 in 10 year design condition was used in the designing of emergency / temporary works (CIRIA, 2007). The SWAN (TU Delft) numerical model wave transformation model was used to analyse the nearshore wave climate and derive the long term nearshore wave statistics. From the nearshore analysis, the design parameters were derived. The emergency design options were then evaluated in a quasi-3D physical model.

\section{Nearshore Wave Direction}

Approximately $58 \%$ of nearshore wave directions fall within the $340^{\circ}$ to $345^{\circ}$ directional bands at the breakwater toe while $2.4 \%$ of the waves result in a nearshore wave direction of between $0^{\circ}$ and $10^{\circ}$ at that location. $11.8 \%$ of the nearshore waves fall within the sector $345^{\circ}$ to $360^{\circ}$. The nearshore directions, $342^{\circ}$ (NW sector) and $4^{\circ}$ (N Sector) at the breakwater toe represent wave occurrences over the whole data set well.

\section{Wave Heights, Wave Peak Period and Water Levels}

Wave refraction analysis produced a nearshore wave height dataset calculated at the breakwater toe. The nearshore dataset was analysed for the 1 in 10 year design water level for all wave conditions in the 15 -year data set with breaking waves at the toe for the NW and $\mathrm{N}$ sector. The projected nearshore wave heights were obtained from a statistical analysis using a two parameter Weibull distribution. The nearshore wave heights for the 1 in 10 year return period derived from the Weibull distribution are 5.06 $\mathrm{m}$ for waves from the NW Sector and $5.63 \mathrm{~m}$ for waves from the N Sector.

The nearshore wave period for waves from each of the wave direction sectors were determined from analysing the peak period with the nearshore wave height calculated at the site. Peak periods of $\mathrm{Tp}=14$ $\mathrm{s}$ for the NW Sector and $\mathrm{Tp}=12 \mathrm{~s}$ for the $\mathrm{N}$ Sector were chosen for the associated 1 in 10 year design condition

The calculated extreme 1 in 10 year water levels, assumed to occur at Mean High High Water (MHHW) and Mean Low Low Water (MLLW) for the site, are $+1.54 \mathrm{~m}$ to CD for the MHHW and +0.94 $\mathrm{m}$ to $\mathrm{CD}$ for the MLLW conditions for both the NW- and N Sectors.

\section{PHYSICAL MODEL}

\section{Aim of the Model Study}

The main aim was to determine the most effective and stable configuration of the dolosse used for the repair. The limitation was the size of the largest possible dolos units that could be taken to the island at the time, which were halves of a $10 \mathrm{t}$ unit. $10 \mathrm{t}$ dolosse were thus elected for testing as this was the maximum size of unit that could be transported to site.

In order to determine the most effective and stable configuration of the $10 \mathrm{t}$ repair dolosse, quasi 3D stability testing for the emergency repairs of the main breakwater was carried out by WSP at the hydraulic laboratory of the CSIR in Stellenbosch, South Africa. This study details the physical model testing that addressed the following:

- Interlocking of $10 \mathrm{t}$ dolos units with the existing $3.5 \mathrm{t}$ units.

- The stability of the $10 \mathrm{t}$ dolos layer.

- Toe stability of the repaired section.

- Integrity of the repair section in relation to the existing unrepaired structure.

Emphasis is placed on the damaged section and associated emergency repairs, and not on the overall breakwater performance. However, some remarks on the latter are mentioned based on the design and physical modelling work executed. 


\section{Model Overview}

The Calshot Harbour model tests were performed at an undistorted scale $\varepsilon$, of 1:42.8 at the CSIR Hydraulics Laboratory in Stellenbosch, South Africa. Due to basin and wavemaker availability with the urgent time constraints, only a $4 \mathrm{~m}$ wide basin was available. This resulted in a quasi-3D model being proposed, which incorporates the bathymetry in one direction with a portion of the breakwater and harbour being constructed for testing. The $4 \mathrm{~m}$ wide flume is $32 \mathrm{~m}$ long and $1 \mathrm{~m}$ deep. All effects of free surface gravity waves were scaled in the physical model by applying Froude scaling (Hughes, 1995).

The following scaling factors were applied:

- Length $\varepsilon \quad 1: 42.8$.

- Time $\sqrt{ } \varepsilon \quad 1: 6.54$.

- Mass $\varepsilon^{3} \quad 1: 78402.7$.

The irregular bathymetry offshore of the breakwater includes shallow reef outcrops and reef formations that cause depth limited wave breaking offshore of the breakwater. An idealised bathymetry profile was extracted for both the directions of $342^{\circ}$ and $4^{\circ}$ from the surveyed data (Tritan Survey cc. ,2010) and extrapolated over the width of the flume for the two main directions. Figure 3 shows the bathymetry long section profile for the two directions. Note the prominent outcrop for the $342^{\circ}$ between points "A" and "B" on Figure 3. The model during the construction phase is shown in Figure 4.



Figure 3. Long sections of the idealized flume bathymetry for the $342^{\circ}$ and $4^{\circ}$ incident wave directions . The red line represents the $342^{\circ}$ while the $4^{\circ}$ direction is represented by the blue line.

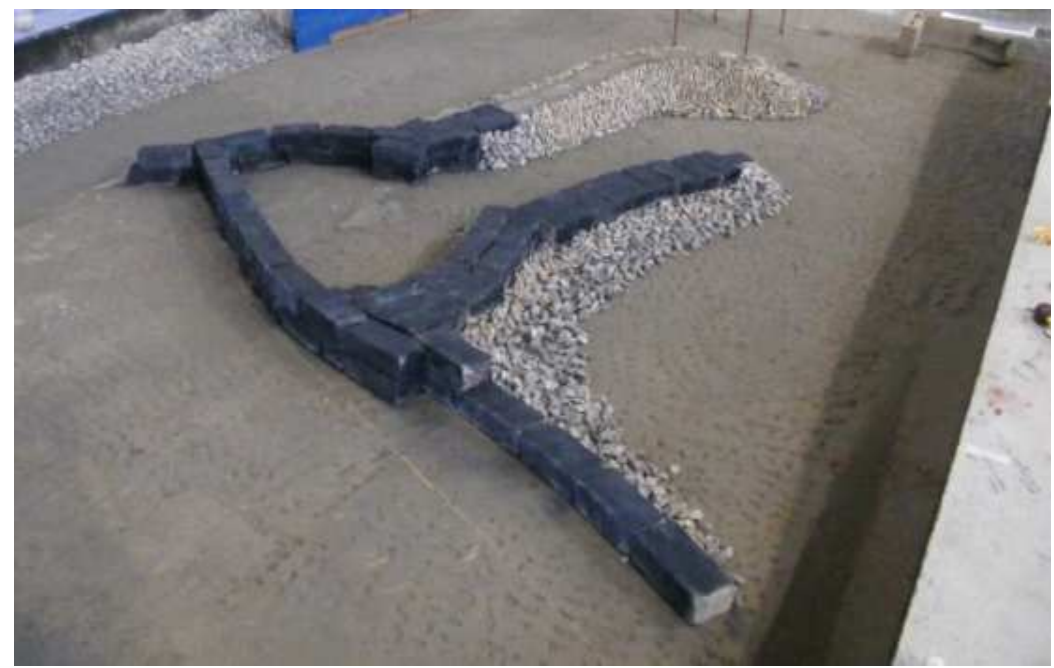

Figure 4. Calshot harbour during model construction phase. 
The test duration for each test was 3200 waves. The storm duration tested was \pm 10 hours for a peak period of 14 seconds and \pm 8.5 hours for 12 seconds (prototype). The model layouts for the two different wave directions are presented in Figure 5.

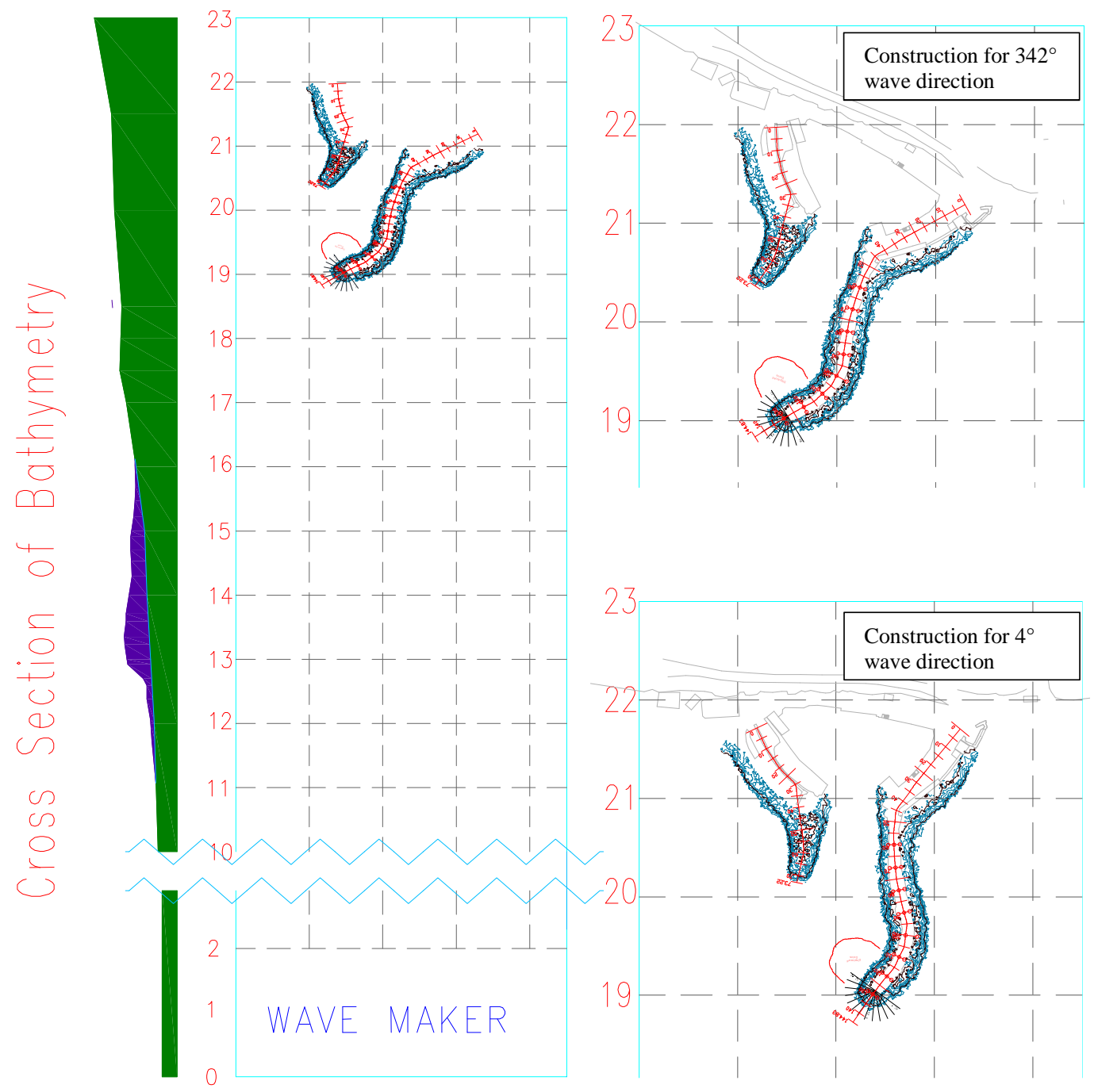

Figure 5. Model layout for $342^{\circ}$ wave direction and $4^{\circ}$ wave direction (CSIR, 2010).

\section{Summary of Model Test Parameters}

The physical model testing parameters at the toe of the structure (nearshore) are given in Table 1.

\begin{tabular}{|lll|}
\hline \multicolumn{3}{|l|}{ Table 1. Summary of quasi-3D testing parameters. } \\
\hline & NW Sector & N Sector \\
\hline Direction (deg) & 342 & 4 \\
Wave Height $(\mathrm{m})$ & 5.06 & 5.63 \\
Peak Period $(\mathrm{s})$ & 14.0 & 12.0 \\
MHHW Water levels $(\mathrm{m})$ & 1.54 & 1.54 \\
MLLW Water level $(\mathrm{m})$ & 0.94 & 0.94 \\
\hline
\end{tabular}




\section{Model Construction and Dolos Packing}

The model was constructed for wave directions from $342^{\circ}$ and $4^{\circ}$. The bathymetry for the wave direction of $4^{\circ}$ was constructed first, after which the bathymetry for waves coming from $342^{\circ}$, which was shallower, was constructed on top of the original bathymetry.

The breakwater roundhead and portion of the trunk was constructed from typical cross-sections of the trunk and roundhead provided by WSP Africa. The core material and armour of the breakwater was then packed simultaneously to best reproduce the original packing method used on Tristan da Cunha. Packing of the trunk section was done with the aid of cross sections while the packing of the round head was done with cross sections as well as photographs taken. The toe and rubble sections consisting of 0 $2 \mathrm{t}$ rock were then also placed according to the templates.

Together with WSP Africa, the assumption was made that the core was impermeable and solid, therefore to ensure the centre of the core remained stable during testing; the capping of the breakwater was constructed with bricks that were screed to the correct level. The images in Figure 6 gives an indication of how the construction was done. Testing of the core for the breakwater was not part of the scope, however to pack the $3.5 \mathrm{t}$ dolosse realistically, core material was placed between the bricks and dolosse (to simulate the original prototype packing of the breakwater).


Figure 6. Breakwater Construction Images.

One of the challenges of the emergency repairs to the breakwater was to interlock the $10 \mathrm{t}$ repair units into the existing 3.5 t slope, taking into account the 1:1 slope and "fence post" type packing of the existing slope. This was done in the physical model using traditional grid placement techniques for the main body of the repair and "blending / interlocking" the $10 \mathrm{t}$ units into the existing slope manually, that is to say, by eye.

\section{Model Test Results}

This section describes the structural stability of the area of breakwater to be repaired with $10 \mathrm{t}$ dolos units. The stability of the armour units was determined by comparing photographs taken before and after each test. Two digital cameras were mounted at fixed positions with a view angle perpendicular to the 
seaward slope. The area of interest was the repaired section and the roundhead (camera station one). Figure 7 indicates the two camera stations.

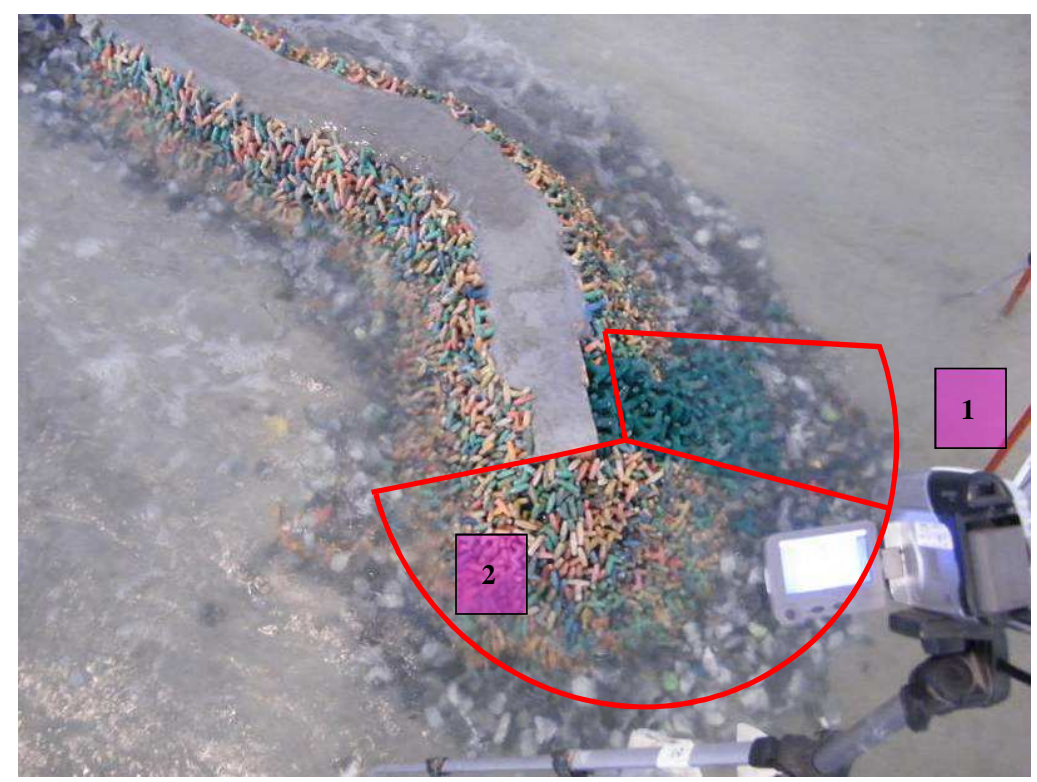

Figure 7. Camera Stations (CSIR, 2010).

Camera station one covered the section of armour where the core material had become severely exposed and threatened the survival of the structure. Stability results for the $3.5 \mathrm{t}$ dolosse on the roundhead (camera station 2) were also taken but only for observation purposes.

For the measurement of damage to the armour units as well as the toe, the armour track method was used as described by Phelp \& Tulsi (2006). The two images were analysed using software developed by CSIR to assess armour unit damage. The displacements were classified as follows:

- $0.25 \mathrm{xH}<=$ Movement $>=0.5 \mathrm{xH} \rightarrow$ settlement.

- $0.5 \mathrm{xH}<=$ Movement $>=1 \mathrm{xH} \quad \rightarrow$ rocking + potential damage.

- Movement $>1.0 \mathrm{xH} \quad \rightarrow$ full displacement.

These classifications are derived from Phelp, (2000), where ' $\mathrm{H}$ ' is the height of a dolos unit. Model dolos units are made of polyester resin and are to scale much stronger than a prototype unit. This result in units not breaking in the model environment. Rocking units during model testing might break in prototype and is therefore accounted for in the calculation of damage.

A total of nine tests were carried out to evaluate the stability of the emergency repair section (shakedown and additional tests excluded). Before every repair option to be tested, the round head consisting of $3.5 \mathrm{t}$ dolosse were repacked. This included recreating the damage as per photographs taken after the August 2010 storm. The repair option to be tested was then constructed. Table 2 presents the wave conditions and test information.

Each repair consisted of placing $10 \mathrm{t}$ dolosse over the section to be repaired. The dolosse were then stitched (joined) into the $3.5 \mathrm{t}$ armour layer. The dolos placement for each repair is described in detail in Table 3. Due to the remoteness and logistical aspects of getting material to Tristan da Cunha, a limited number of $10 \mathrm{t}$ dolosse (75 in total) were available for each repair option to be tested. Figure 8 shows how one of the repair options was constructed. 


\begin{tabular}{|c|c|c|c|c|c|c|c|}
\hline Test No. & $\begin{array}{l}\text { Wave } \\
\text { Direction }\end{array}$ & $\mathrm{WL}(\mathrm{CD})$ & Waves & ${ }^{*} \mathrm{Hm} 0$ & $\mathrm{H} 1 / 3$ & $\mathrm{Tp}$ & Test Duration \\
\hline Test 002 & $342^{\circ}$ & $+1.54 \mathrm{~m}$ & 3200 & $5.0 \mathrm{~m}$ & $5.7 \mathrm{~m}$ & $14.0 \mathrm{~s}$ & $\begin{array}{l}\text { Stopp ed } 2 \text { hours and } 50 \\
\text { minutes into a } 10 \text { hour storm }\end{array}$ \\
\hline Test 004 & $342^{\circ}$ & $+1.54 \mathrm{~m}$ & 3200 & $5.0 \mathrm{~m}$ & $5.8 \mathrm{~m}$ & $14.0 \mathrm{~s}$ & $\begin{array}{l}\text { Stopp ed } 7 \text { hours into a } 10 \text { hour } \\
\text { storm }\end{array}$ \\
\hline Test 005 & $342^{\circ}$ & $+1.54 \mathrm{~m}$ & 3200 & $5.0 \mathrm{~m}$ & $5.7 \mathrm{~m}$ & $14.0 \mathrm{~s}$ & $\begin{array}{l}\text { Stopp ed } 9 \text { hours and } 25 \\
\text { minutes into a } 10 \text { hour storm }\end{array}$ \\
\hline Test 007 & $342^{\circ}$ & $+0.94 \mathrm{~m}$ & 3200 & $4.5 \mathrm{~m}$ & $5.1 \mathrm{~m}$ & $14.5 \mathrm{~s}$ & Full test cycle (10 hour storm) \\
\hline $\begin{array}{r}{ }^{* *} \text { Test } \\
008\end{array}$ & $342^{\circ}$ & $+0.94 \mathrm{~m}$ & 1000 & $4.7 \mathrm{~m}$ & $6.8 \mathrm{~m}$ & $14.8 \mathrm{~s}$ & Full test cycl e (3.1 hour storm) \\
\hline Test 010 & $342^{\circ}$ & $+1.54 \mathrm{~m}$ & 3200 & $4.5 \mathrm{~m}$ & $6.8 \mathrm{~m}$ & $14.0 \mathrm{~s}$ & $\begin{array}{l}\text { Stopp ed } 1 \text { hour and } 40 \text { minutes } \\
\text { into a } 10 \text { hour storm }\end{array}$ \\
\hline Test 012 & $4^{\circ}$ & $+1.54 \mathrm{~m}$ & 3200 & $4.7 \mathrm{~m}$ & $5.5 \mathrm{~m}$ & $* \star *$ & Full test cycle ( 8.5 hour storm) \\
\hline $\begin{array}{r}\text { ** Test } \\
013\end{array}$ & $4^{\circ}$ & $+1.54 \mathrm{~m}$ & 1000 & 5.00 & $5.8 \mathrm{~m}$ & $13.7 \mathrm{~s}$ & Full test cycle ( 2.7 hour storm) \\
\hline Test 015 & $4^{\circ}$ & $+0.94 \mathrm{~m}$ & 3200 & $4.6 \mathrm{~m}$ & $5.2 \mathrm{~m}$ & $* \star *$ & Full test cycle ( 8.5 hour storm) \\
\hline $\begin{array}{r}{ }^{* *} \text { Test } \\
016\end{array}$ & $4^{\circ}$ & $+0.94 \mathrm{~m}$ & 1000 & $4.8 \mathrm{~m}$ & $5.4 \mathrm{~m}$ & $* * *$ & Full test cycle (2. 7 hour storm) \\
\hline Test 019 & $4^{\circ}$ & $+2.00 \mathrm{~m}$ & 3200 & $5.0 \mathrm{~m}$ & $5.8 \mathrm{~m}$ & $* * *$ & $\begin{array}{l}\text { Stopped } 3 \text { hours and } 57 \\
\text { minutes into a } 8.5 \text { hour storm }\end{array}$ \\
\hline
\end{tabular}

* This is the $\mathrm{H}_{\mathrm{m} 0}$ in front of the structure

** The test was carried out with an output gain of $20 \%$ larger than calibrated

*** False wave period measurements caused by wave plunging near the probe

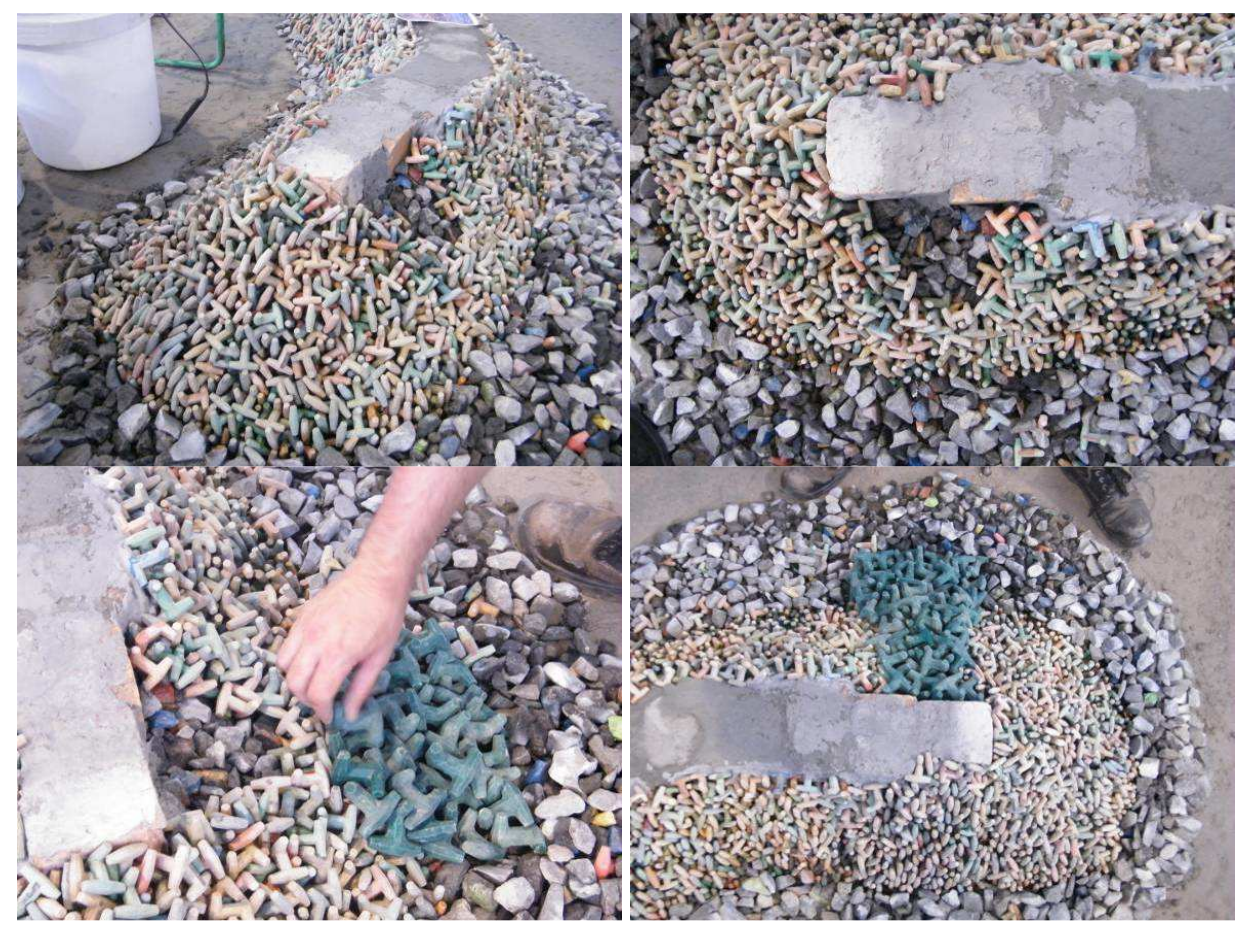

Figure 8. Breakwater Construction Images for Test 004. 


\begin{tabular}{|c|c|}
\hline Test No. & Packing \\
\hline Test 002 & $\begin{array}{l}3.5 \mathrm{t} \text { dolos units placed to best reproduce existing profile, layer thickness and interlocking of the } \\
\text { head, trunk and damaged area of the breakwater. Dolos units on the trunk section were packed in a } \\
\text { "fence post" formation. The roundhead was packed randomly with the top armour of the breakwater } \\
\text { packed loosely. The section to be repaired was packed with } 75,10 \text { tolos units stitched into the } 3.5 \\
\text { t armour layer. The repair dolosse were packed double layer at a slope } 1: 1 \text { with a density of roughly } \\
1.05 \text {. }\end{array}$ \\
\hline Test 004 & $\begin{array}{l}\text { Armour layer on seaward side of roundhead packed randomly as in Test_002 but slightly denser. } \\
\text { The leeward side of the roundhead the armour layer was packed using a "fence post" method instead } \\
\text { of the random packing method used for Test_002. Although the packing of the } 3.5 \mathrm{t} \text { armour layer } \\
\text { was more realistic for Test_002, the main focus was the } 10 \mathrm{t} \text { dolosse on the repaired section and } \\
\text { not the roundhead. Therefore the roundhead was packed slightly denser for Test_004 in the hope } \\
\text { that if the roundhead failed it would not have such a great influence on the stability results of the } \\
\text { repaired section as in Test_002. The } 10 \text { t repair section had the same packing placement and density } \\
\text { as in Test_002. }\end{array}$ \\
\hline
\end{tabular}

Test 005 This was an additional test, most of the $3.5 \mathrm{t}$ armour layer on the roundhead was replaced with an additional 75, $10 \mathrm{t}$ units packed randomly. The repair section was again packed in the same manner as for Test_002 and Test_004. The repair section had the same packing placement and density as in Test_002.

Test 007 The main reason for undertaking this test was to determine the stability for the toe of the $10 \mathrm{t}$ repair dolosse. Because of this, most of the roundhead was packed with a "fence post" method. The repair section had the same packing placement and density as in Test_002.

Test 008 Overload condition. No repacking of the roundhead and trunk was done; the test was run directly after Test_007.

Test 010 Main reason for test was to determine if the cause of the roundhead failure during tests 002,004 and 005 are indirectly as a result of the section repaired with the 10 t dolosse. As for Test 002 the armour layer was packed realistically, using survey photographs with single layer areas on the roundhead to recreate the damage caused by the previous storms. The roundhead was packed randomly with the top armour of the breakwater packed loosely. The damage on the section to be repaired was re-created using survey photographs taken after the previous storms. No repair was made. For this test the damaged mass capping at the front of the roundhead was also modelled using 4 individual pieces of flat rock that were screed together with rock set cement. The mass of the individual pieces were $135 \mathrm{t}$, prototype. Note that this is slightly conservative in terms of breakwater stability, with the existing cap having an estimated weight of about $110 \mathrm{t}$.

Test 012 The $3.5 \mathrm{t}$ dolosse packed as for Test 004 . The $10 \mathrm{t}$ dolosse were not packed all the way up to the mass capping but had three rows of random placed dolosse at the top. The repair section had the same packing placement and density as in Test_002.

Test 013 During Test_012 the main integrity of the structure survived the full 8.5 hour storm duration. Test 013 was setup as an overload condition for Test 012 . While the roundhead and trunk section was not repaired for the Test_013, The 10 t dolosse were repacked onto the section being repaired. During the repacking of the $10 \mathrm{t}$ dolosse it is important to note that unlike for Test- 012 , the dolosse were packed right up against the mass capping.

Test 015 As for Test 013 , the dolosse were packed to right up against the mass capping. The strip of 75,10 $\mathrm{t}$ dolosse were more densely packed together with 2 to 3 fewer units per row. The repair dolosse were packed double layer with a density greater than 1.15 .

Test 016 During Test_015 the section repaired with $10 \mathrm{t}$ units was still intact with the roundhead of the breakwater damaged. Test_016 was set-up as an overload condition for Test_015.

Test 019 The packing of the armour units was done in the same manner as for Test_012, but with some $3.5 \mathrm{t}$ units now placed randomly on the top half of the roundhead. 


\begin{tabular}{|c|c|c|c|c|c|}
\hline \multirow[b]{2}{*}{ Water Level } & \multirow[b]{2}{*}{ Section of interest } & \multicolumn{2}{|c|}{$\begin{array}{l}\text { Movement for } 342^{\circ} \\
\text { wave direction }\end{array}$} & \multicolumn{2}{|c|}{$\begin{array}{l}\text { Movement for } 4^{\circ} \\
\text { wave direction }\end{array}$} \\
\hline & & $0.5 \mathrm{H}-\mathrm{H}$ & $>\mathrm{H}$ & $0.5 \mathrm{H}-\mathrm{H}$ & $>\mathrm{H}$ \\
\hline \multirow{4}{*}{$\begin{array}{l}+1.54 \mathrm{~m}(\mathrm{CD}) \\
\text { Normal } \\
\text { condition }\end{array}$} & All 75 units & 5 units & 11 units & 1 units & 2 units \\
\hline & Toe Section & 1 unit & 0 unit & 0 units & 0 units \\
\hline & Roundhead stitching & 0 units & 5 units & 0 units & 0 units \\
\hline & Trunk stitching & 1 units & 2 units & 2 units & 0 units \\
\hline \multirow{4}{*}{$\begin{array}{l}+1.54 \mathrm{~m}(\mathrm{CD}) \\
\text { Overload } \\
\text { Condition }\end{array}$} & All 75 units & ------- & ------- & 0 units & 6 units \\
\hline & Toe Section & ------- & ------- & 0 units & 0 units \\
\hline & Roundhead stitching & ------- & ------- & 0 units & 0 units \\
\hline & Trunk stitching & ------- & ------- & 0 units & 5 units \\
\hline \multirow{4}{*}{$\begin{array}{l}+0.94 \mathrm{~m}(\mathrm{CD}) \\
\text { Normal } \\
\text { Condition }\end{array}$} & All 75 units & 1 unit & 0 unit & 0 unit & 1 unit \\
\hline & Toe Section & 0 units & 0 units & 0 units & 0 units \\
\hline & Roundhead stitching & 0 units & 0 units & 0 units & 0 units \\
\hline & Trunk stitching & 1 unit & 0 unit & 0 unit & 1 unit \\
\hline \multirow{4}{*}{$\begin{array}{l}+0.94 \mathrm{~m}(\mathrm{CD}) \\
\text { Overload } \\
\text { Condition }\end{array}$} & All 75 units & 0 units & 4 units & 1 units & 3 units \\
\hline & Toe Section & 0 units & 0 units & 0 units & 0 units \\
\hline & Roundhead stitching & 1 unit & 0 unit & 0 units & 0 units \\
\hline & Trunk stitching & 0 units & 3 units & 1 units & 3 units \\
\hline \multirow{4}{*}{$\begin{array}{l}+2.0 \mathrm{~m}(\mathrm{CD}) \\
\text { Extreme } \\
\text { condition }\end{array}$} & All 75 units & ------- & ------- & 1 units & 1 units \\
\hline & Toe Section & ------- & ------- & 0 units & 0 units \\
\hline & Roundhead stitching & -------- & -------- & 0 unit & 1 unit \\
\hline & Trunk stitching & ------ & -------- & 1 units & 0 units \\
\hline
\end{tabular}

Although a lot of settling of dolos units took place for both of the wave directions tested, only a few units were displaced a distance lager than $0.5 \mathrm{xH}$ for each test. Table 4 illustrates the average number of dolosse displaced more than $0.5 \mathrm{xH}$ for all the tests at the same water level and condition. When more than 5 units were displaced a distance of $0.5 \mathrm{xH}$ or greater, it was usually as a result of the roundhead failing up to the repaired section.

For both wave directions the toe of the $10 \mathrm{t}$ repair sections were found to be stable. The stitching between the $3.5 \mathrm{t}$ and $10 \mathrm{t}$ dolosse, sustained little or no damage during all the tests. When some damage occurred between the stitching on the roundhead side, it was mostly because of the roundhead failing. When the roundhead remained intact, no displacements were observed.

The start of failure in all the tests was always on the section of roundhead not being repaired. Test 010 proved that the roundhead failures were not a result of the $10 \mathrm{t}$ dolos units on the repair section (refer to Table 3 for the packing without the $10 \mathrm{t}$ dolos units). Figure 9, shows a sequence of the images illustrating the failure from start to finish without a repair done.
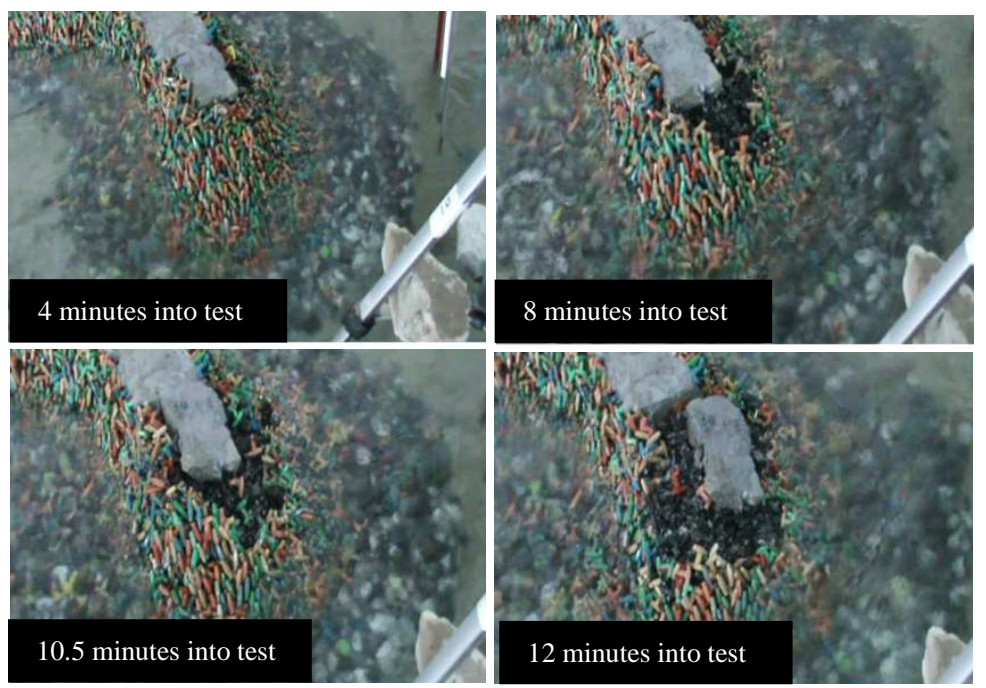

Figure 9. Breakwater Failure Image Sequence for Test 010. 
Although only photographs were used to recreate the damage on the roundhead before a repair was made, the results show that all the different packing arrangements and densities tested using $10 \mathrm{t}$ dolos units for the repair were stable for the 1:10 year storm conditions tested. The general conclusion which can be drawn from the model tests is that even if practical reasons on site results in a slightly different packing arrangement for the repair, the planned repairs using 75, $10 \mathrm{t}$ dolosse will be successful as an emergency repair to protect the existing damaged area from a 1:10 year storm.

\section{ONSITE CONSTRUCTION}

\section{Initiation of Emergency Repairs}

Based on the WSP's proposed repair options, the client initiated the temporary Emergency Repairs of the damaged breakwater to be executed in the 2010/11 summer (December 2010 to April 2011).

These included:

- Placement of $10 \mathrm{t}$ armour units in the harbour's damaged west breakwater under expert direction.

- Stabilisation of the broken capping slab by underpinning with mass concrete, dowelled into the existing slab.

- The required number of armour units (estimated at 80 in the early stages of the project) would be cast in South Africa and then transported by ship to Tristan da Cunha, although the possibility of setting up a precast facility on island was to be investigated. It was anticipated that this approach would only require a single return trip by the chartered vessel, the Baltic Trader.

- Procurement and shipment of an appropriate crane to carry out the repair work (this crane would be sold to the Island on project completion).

- The logistical arrangement, insurance and vessel charter to execute the above.

The dolosse were cast as halves in Hermanus, South Africa, and stitch cast to whole units on site at Tristan da Cunha, see Figure 10.

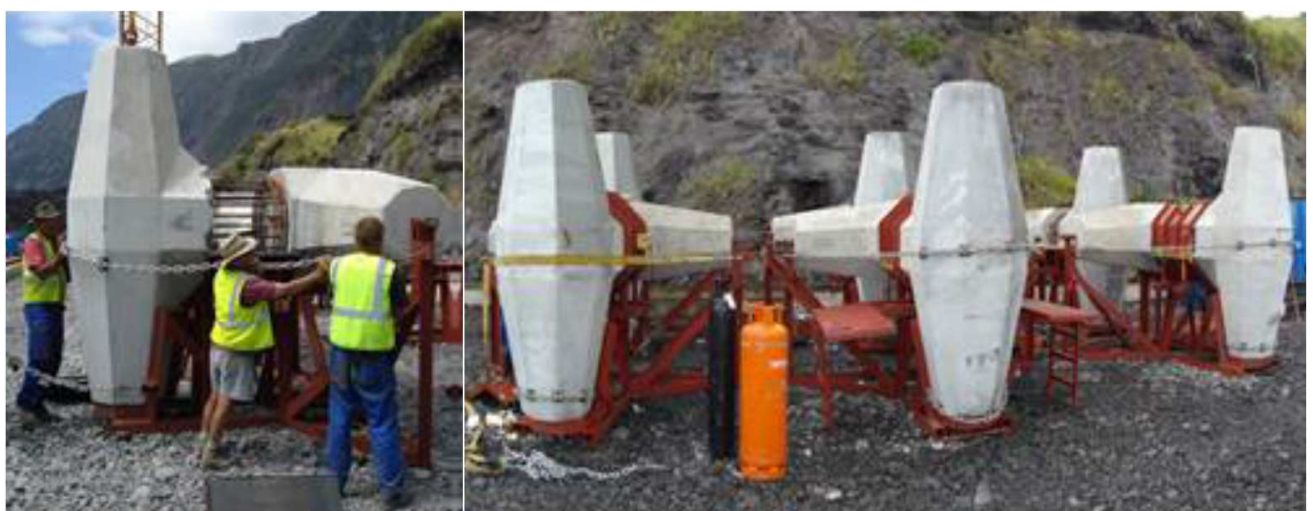

Figure 10. Stitch casting yard at Tristan da Cunha

\section{Sequence of Emergency Repairs}

The appointed Contractor and Logistics team were Sea \& Shore Projects and TPS respectively. Repair of the damaged dolos slope structure was successfully carried out in the following sequence:

- The dolos repair was completed by removing the broken dolosse and large temporary rocks, dumped by the islanders, from the damaged area on the breakwater slope.

- The profile slope armour was dressed to within specification tolerances. Displaced dolosse and rock directly adjacent to the repair section were repositioned in the slope to allow for knitting of the repair 10 tonne dolos units into the existing profile.

- Armour rock underlayer was placed and dressed to the design slope of 1:1.5 to within specification tolerances by excavator, above water, and a crane fitted with a hydraulic grab for submarine slope profiling. Undulations in the damaged rock slope were filled first to ensure a uniform armour rock underlayer. The rock underlayer was consisted of $1.5 \mathrm{t}$ to $3 \mathrm{t}$ pieces. A trench was excavated by hydraulic grab to act as a footing to stabilize the dolos slope. This trench received the first layer of dolosse at the toe of the slope. Rock and broken dolos units excavated from the toe trench or an over-profiled slope were removed to a nearby stockpile. The stockpiled material was later used to construct a rock-toe at the base of the dolos slope to act as an additional "kicker" and the remainder 
was used as primary armour for a revetment protection for the crane storage area situated at the eastern beach.

- 80 No. $10 \mathrm{t}$ dolosse were carefully packed on a prescribed grid to ensure that the required packing density of the dolosse was attained. Placement of a double layer (approximately $3.0 \mathrm{~m}$ thick) using the industry accepted packing sequence to ensure optimal interlocking between the $10 \mathrm{t}$ dolos units was done. All broken or damaged units occurring during placement were removed from the breakwater. The $10 \mathrm{t}$ dolosse were knitted into the existing $3.5 \mathrm{t}$ dolosse adjacent to the repair section with as smooth a transition as was practicably possible, with minimal disturbance of the $3.5 \mathrm{t}$ units on either side of the damaged area. All subsurface dolosse placed were carefully positioned by the contractor diver and resident engineer who were in the water during each placement, as time constraints did not allow for traditional inspection and repacking techniques.

Various stages of construction are shown in Figure 11.

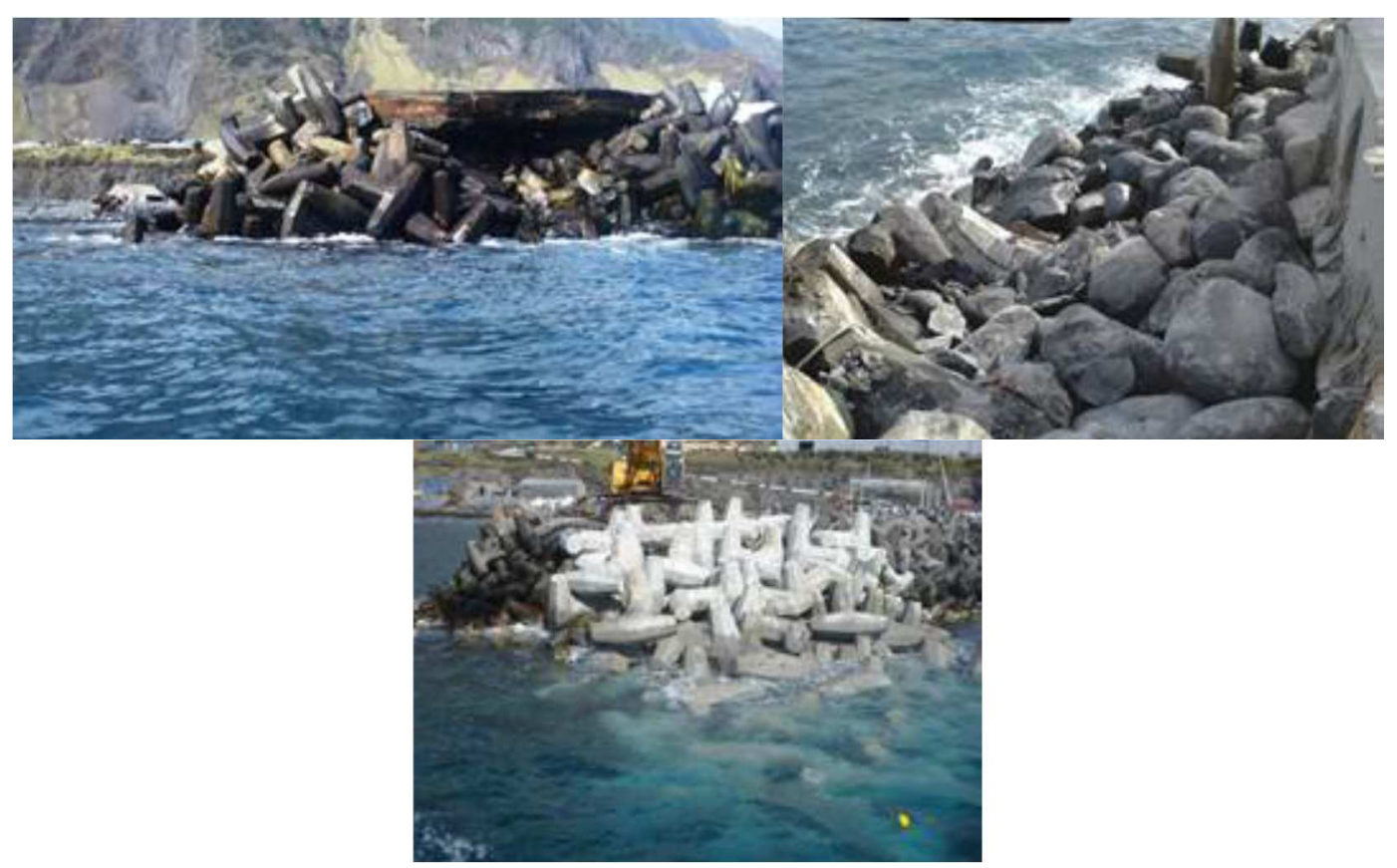

Figure 11. Stages of construction (left to right). (1) The damaged section of the Western Breakwater upon arrival of repair team; (2) the dressed armour slope; (3) completed repair - 1 April 2011.

\section{As-build Positions of Emergency Repair Dolosse}

The physical modelling exercise of experimental packing techniques proved invaluable to the team that went to site. Figure 12 shows the as-built positions of the emergency dolosse in relation to the design grid. 


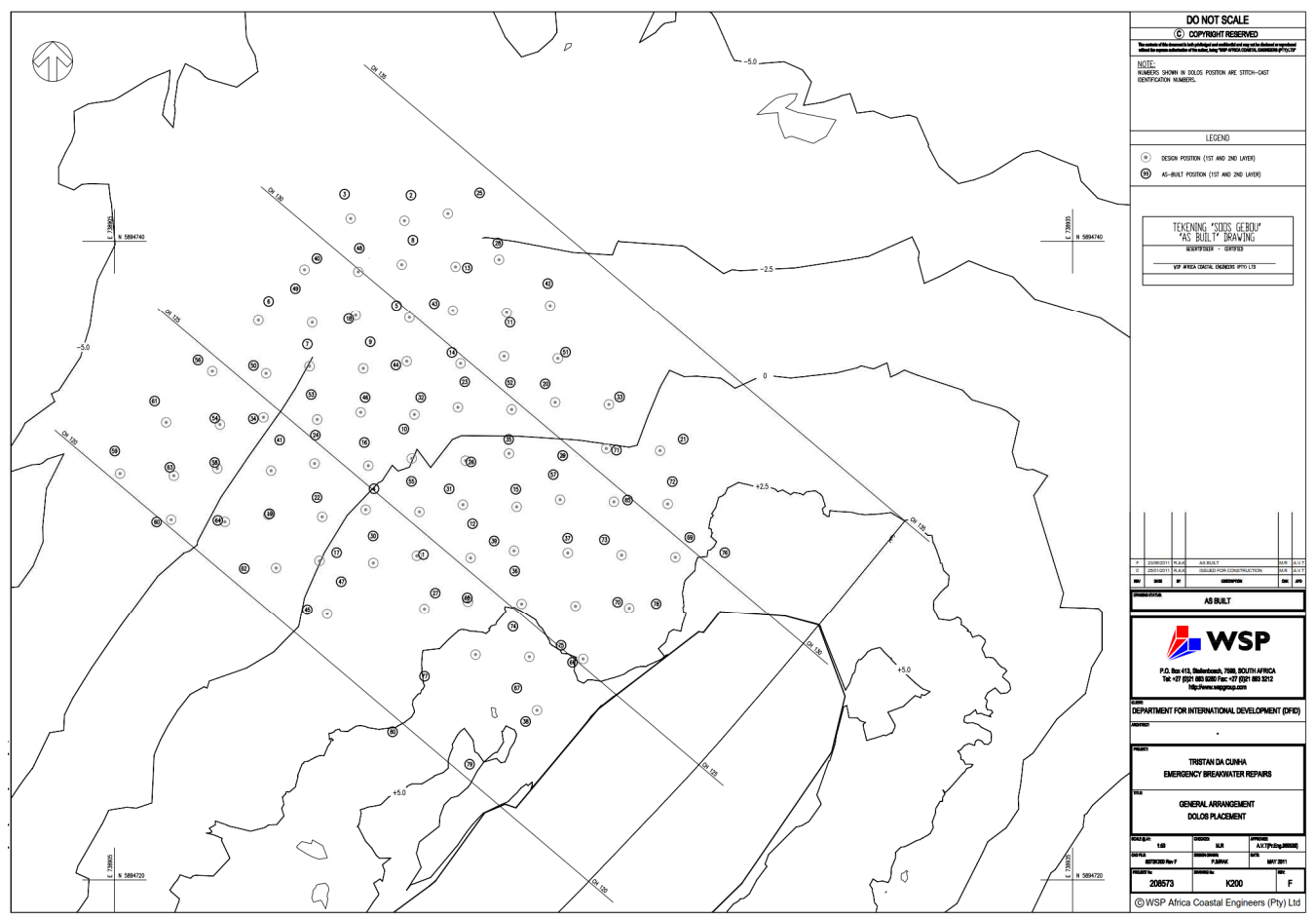

Figure 12. As-built positions of emergency repair dolosse.

\section{Repair of the Damaged Breakwater Cap:}

The existing cap was broken up by means of a hydraulic breaker and then, leaving the demolished material as it lay, mass capping was cast on top of this section of concrete. The concrete cap was demolished into four sections of approximately 20 tonnes each. No vehicles or personnel were allowed on top of the mass capping before it was properly repaired, including the crane for dolos placement. In an effort to increase the weight of the cap, shear links with reinforcing were drilled through the existing cap into the filling underneath to add mass to the structure. Refer to Figure 13 for stages of the repair.

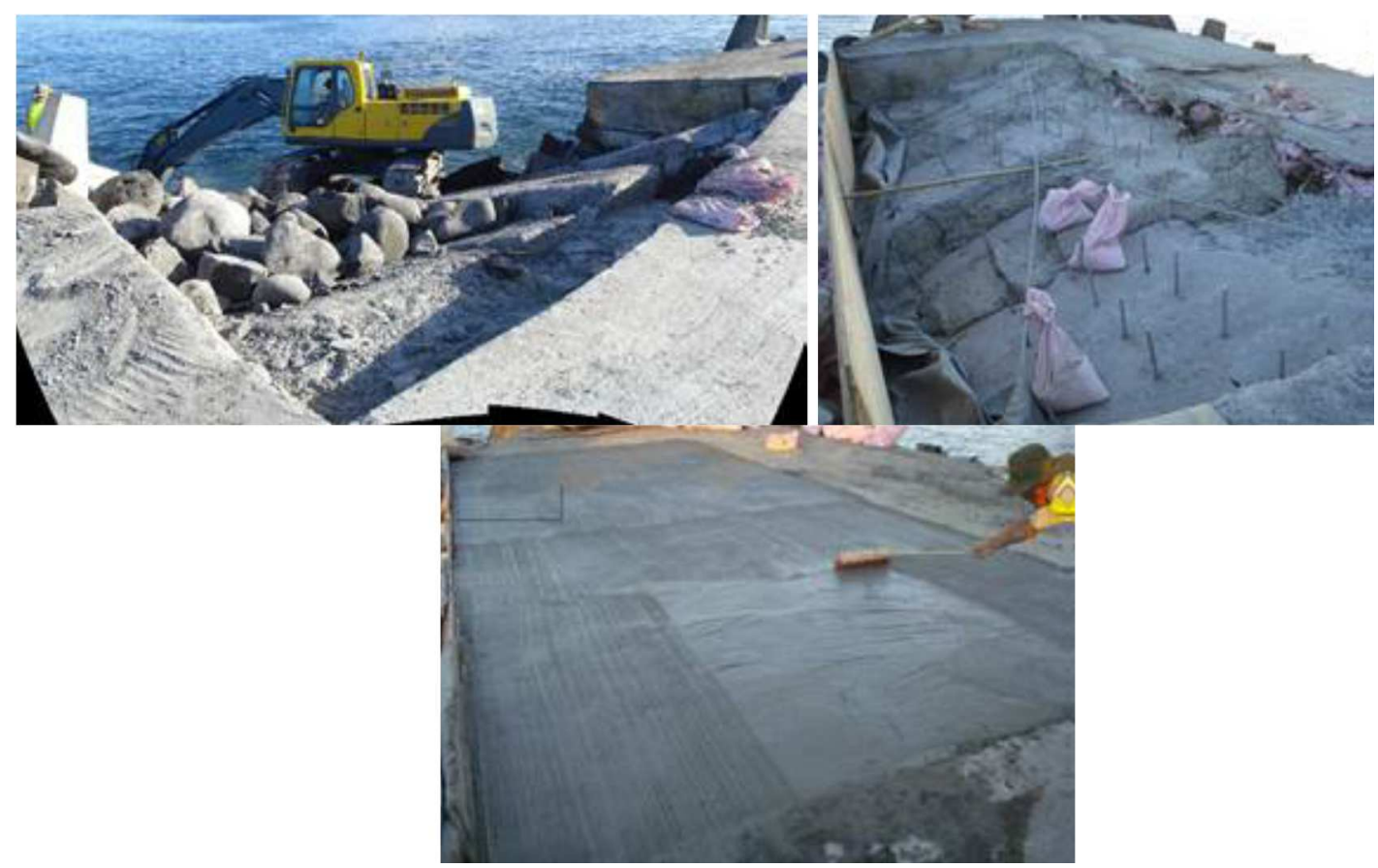

Figure 13. Stages of the concrete cap repair. 


\section{CURRENT STATUS OF REPAIR AND CONCLUSION}

WSP (2012) reports that the $10 \mathrm{t}$ dolos repair section as constructed between January and April 2011 by Sea \& Shore is still in good condition. Of the 80 units placed, three are displaced, three badly broken and two damaged. No immediate action is required and no construction defects were evident. Further work at the roundhead has taken place in 2012 where $3.5 \mathrm{t}$ locally made dolos units were placed to bolster the roundhead protection. The other project related work executed under the same project is also in satisfactory condition without any defects requiring remedial measures.

Emergency repairs to the western breakwater at Tristan da Cunha were designed and constructed with exceptionally tight deadlines. The lessons learned through physical model tests in the laboratory were of great value to the construction team on the ground. By testing various placement and interlocking configurations, an effective construction methodology was developed and successfully implemented on site.

\section{REFERENCES}

CIRIA, CUR, CETMEF (2007). Rock Manual. The use of rock in hydraulic engineering. (second edition). C683, CIRIA, London.

CSIR (2010), Roundhead Repair Stability Test for Tristan da Cunha Harbour, Quasi 3D Physical Model Test, February 2011, Stellenbosch, South Africa. Report number CSIR/BE/IE/ER/2011/0005/B

Halcrow (2005) Tristan da Cunha - harbour construction. Final Report. Halcrow group Limited. March 2005.

Hughes, S.A., 1995. Physical Models and Laboratory Techniques in Coastal Engineering, World Scientific, Singapore. ISBN-10: 9810215401.

Phelp, D. \& Tulsi, K., 2006. Digital Image Technology as a Measurement Tool in Physical Models, Coastal Lab 2006 - $1^{\text {st }}$ International Conference on the Application of Physical Modelling to Port and Coastal Protection, Porto, Portugal.

Phelp, D \& Zwamborn, J. A., 2000. Correlation between Model and Prototype Damage of Dolos Breakwater Armouring, Coastal Engineering $2000-27^{\text {th }}$ Conference on Coastal Engineering, Sidney, Australia.

Tritan Survey cc. (2010). Calshot Harbour Survey. Tritan Survey cc.

Vonk, R., Phelp, D., Boysons, C., Edries, R., 2007. Survey of the old dolos breakwaters, Tristan da Cunha, Coastal Structures 2007 - $5^{\text {th }}$ International Conference, Venice, Italy, $92-103$.

Webb, R. M. (1999). Tristan da Cunha Harbour Development Pre-Feasibility Study Final Report. Colchester: Robin Webb Consulting Limited.

WSP (2010), Tristan da Cunha - Calshot Harbour Interim Final Assessment Report, October 2010, WSP Africa Coastal Engineers, Stellenbosch, South Africa.

WSP (2011), "Tristan da Cunha - Calshot Harbour Final Assessment Report", WSP Africa Coastal Engineers, Stellenbosch, South Africa, April 2011.

WSP (2012), Defects Liability Inspection Report, 2010/11 Temporary Emergency Repairs on Tristan da Cunha Breakwater, June 2012, WSP Africa Coastal Engineers, Stellenbosch, South Africa. 